\title{
BIBLIOTEKI KOLEGIACKIE W DIECEZJI KRAKOWSKIEJ W OKRESIE PRZEDROZBIOROWYM
}

\section{Wstęp}

Diecezja krakowska w okresie Polski przedrozbiorowej posiadała największą liczbę kapituł kolegiackich. Podczas gdy prymasowska archidiecezja gnieźnieńska liczyła ok. 1772 roku 10 kolegiat, wrocławska 8, poznańska 7, to krakowska miała ich 20 (wliczając w to zanikłe i cząstkowe) ${ }^{1}$.

Nie wszystkie posiadają swoje opracowania. Ponadto istniejące, nie poruszają dogłębnie wszystkich elementów funkcjonowania tych wspólnot kanonickich. W grupie tych zagadnień znajdują się również biblioteki. Niniejsze rozważania nie aspirują do miana pełnego przedstawienia dziejów tych księgozbiorów. Stanowią raczej próbę ukazania wybranych aspektów ich funkcjonowania oraz wysunięcie postulatu kompleksowego opracowania tego zagadnienia. Skupiają się ponadto na kolegiatach umiejscowionych poza stołecznym dla diecezji Krakowem

Z dotychczasowych opracowań naukowych traktujących wprost o bibliotekach kolegiackich należy wymienić artykuły P. Kardysia ${ }^{2}$, J. Wolnego ${ }^{3}$, i W. Wój$\mathrm{cika}^{4}$. W Uniwersytecie Jana Kochanowskiego w Kielcach tematykę tę w ramach pracy magisterskiej podjął A. Witczak ${ }^{5}$. Ponadto wiele cennych informacji dotyczących tego zagadnienia podaje B. Kumor w trzecim tomie Dziejów diecezji krakowskiej do 1795 roku, podczas omawiania funkcjonowania poszczególnych ko-

${ }^{1}$ B. Kumor, Dzieje diecezji krakowskiej do roku 1795, t. 2, Kraków 1999, s. 360.

${ }^{2}$ P. Kardyś, Biblioteka przykolegiacka w Wiślicy (XV-XVIII wiek), „Archiwa Biblioteki i Muzea Kościelne" (dalej: ABMK), 82 (2005) s. 85-102.

${ }^{3} \mathrm{~J}$. Wolny, Inventaire des manustrits théologique médievaux de la bibliothèque de chaptire à Kielce, ,Mediaev. Philos. Pol.”, 16 (1971) s. 43-85.

${ }^{4}$ W. Wójcik, Archiwum i biblioteka kapituły w Sandomierzu, ABMK, 7 (1963) s. 5-41; tenże, Rękopisy Biblioteki Kapitulnej w Sandomierzu, ABMK, 36 (1978) s. 79-103; tenże, Starodruki w Bibliotece Kapituly Sandomierskiej, ABMK, 37 (1978) s. 249-259.

${ }^{5}$ A. Witczak, Biblioteka kolegiacka w Kielcach $w$ XVII-XVIII wieku (informacja od autora magisterium z kwietnia 2009). 
legiat ${ }^{6}$. Należy również wskazać opracowania W. Gałązki ${ }^{7}$, S. Salaterskiego ${ }^{8}$, J. Szymańskiego ${ }^{9}$, w których można znaleźć cenne materiały dotyczące librarii kapitulnych. Zważywszy jednak na bogactwo źródeł, ważność tematyki oraz szczupłość dotychczasowej literatury można stwierdzić, że temat dotychczas nie został gruntownie opracowany.

\section{Powstawanie bibliotek}

Przyjmując układ chronologiczny, B. Kumor podzielił kolegiaty umiejscowione poza Krakowem na te, które powstały we wczesnym średniowieczu (w Sandomierzu, Wiślicy, Kielcach, Skalbmierzu, Opatowie), późnośredniowieczne (w Tarnowie, Pińczowie, Nowym Sączu, Wojniczu), oraz XVI i XVIIwieczne (w Bobowej, Lublinie, Pilicy, Klimontowie). Czy da się te same ramy chronologiczne przyłożyć do bibliotek?

Wśród kolegiat powstałych we wczesnym średniowieczu istnienie sandomierskiej biblioteki kolegiackiej możemy datować na koniec wieku XII a więc do czasu erygowania kapituły ${ }^{10}$. O wczesnym gromadzeniu książek przy kolegiacie możemy wnioskować z faktu, iż po katedrze krakowskiej była ona pierwszym zgromadzeniem kanoników w ówczesnej diecezji krakowskiej. W tej kapitule zasiadali tak znamienici uczeni tamtych czasów, jak np. bł. Wincenty Kadłubek. Nie bez znaczenia był również fakt istnienia szkoły kolegiackiej. Warto również wspomnieć, iż ustawy synodów średniowiecznych wielokrotnie nakazywały posiadanie przez duchownych opracowań i podręczników z zakresu kaznodziejstwa czy kanonów penitencjalnych ${ }^{11}$.

Wczesną metryką mogła poszczycić się również biblioteka kapituły kieleckiej. Umieszczona była w kapitularzu i zakrystii. W świetle wizytacji z 1598 roku zawierała wiele ksiag liturgicznych oraz 104 woluminy ksiag teologicznych, prawniczych, historycznych i filozoficznych ${ }^{12}$.

Z kolei późnośredniowieczna kapituła kolegiacka w Nowym Sączu trosce o bibliotekę oraz archiwum nie poświęcała zbyt wiele czasu. Wystarczy wskazać fakt, iż istniejąca od 1448 roku korporacja kanoników w tym mieście, mogła podczas wizytacji dokonanej przez kardynała Radziwiłła w końcu XVI wieku wykazać się 12 książkami ${ }^{13}$. Należałoby się spodziewać większej librarii, aczkolwiek jak zauważył badacz przeszłości taj kapituły, S. Salaterski: „Członkowie kapituły parający się nauką, byli związani z uniwersytetem lub rezydowali po parafiach,

${ }^{6}$ Kumor, Dzieje, t. 3, passim.

${ }^{7}$ W. Gałązka, Kapituła kolegiacka w Opatowie w latach 1562-1768, Sandomierz 1997.

${ }^{8}$ S. Salaterski, Kolegiata i kapituła św. Małgorzaty P. M. W Nowym Saczu (1448-1791), Nowy Sącz 1997.

${ }^{9}$ J. Szymański, Kapituła kolegiacka w Wojniczu 1465-1786, Lublin 1962.

${ }^{10}$ Kumor, Dzieje, t. 3, s. 80.

${ }^{11}$ W. Wójcik, Archiwum i biblioteka kapituly w Sandomierzu, ABMK, 7 (1963) s. 30.

${ }^{12}$ Kumor, Dzieje, t. 3, s. 168-169.

${ }^{13}$ Salaterski, Kolegiata, s. 210-211. 
bywając tylko od czasu do czasu przy kolegiacie, natomiast tych, którzy byli blisko kolegiaty, daleko bardziej absorbowały sprawy jej remontów, wyposażenia lub uzyskania należnych czynszów, niż książki (...). Wydaje się, że rola książek i biblioteki w działalności kapituły nie była należycie traktowana ${ }^{14 "}$.

O wiele późniejszą metrykę posiada libraria wojnicka. Najprawdopodobniej została on zorganizowana w XVI stuleciu w skarbcu kościelnym ${ }^{15}$. Z kolei biblioteka w Pilicy ukazana w świetle wizytacji z 1598 roku posiadała księgi liturgiczne i nieokreślone bliżej księgi do nauczania ludu ${ }^{16}$.

Nie wdając się w dalsze rozważania można stwierdzić, że informacje o początkach bibliotek w pozostałych kolegiatach wiążą się najczęściej z ich funkcjonowaniem, stwierdzonym podczas wizytacji biskupich lub zawartym w księgach posiedzeń. Nie zawsze udaje wskazać się czas ich powstania, tym niemniej wydaje się, że realizacja Służby Bożej lub istnienie szkoły przykolegiackiej suponowały istnienie księgozbioru.

\section{Tworzenie księgozbioru}

Zasoby bibliotek były powiększane $\mathrm{w}$ głównej mierze przez darowizny, zapisy testamentowe, zakupy oraz drogą wymiany. Bywały również wypadki, iż księgozbiory kolegiackie przejmowały librarie innych instytucji kościelnych. Tytułem egzemplifikacji można wskazać bibliotekę kapitulną w Sandomierzu, która w końcu XVIII wieku wzbogaciły się o zbiory miejscowego seminarium duchownego, klasztoru i kolegium jezuickiego oraz kościoła św. Piotra ${ }^{17}$. Spoglądając na tytuły przekazywanych dzieł, były to głównie książki kaznodziejskie, traktaty teologiczne i moralne, prawne oraz filozoficzne ${ }^{18}$.

Wśród ofiarodawców książek bardzo często możemy wskazać osoby, które odgrywały wybitną role w ówczesnym życiu religijnym i kościelnym. Wydaje się więc właściwym przypomnienie kilku postaci o których pamięć, nawet na gruncie lokalnym, jest często znikoma.

Dla biblioteki w kolegiacie sandomierskiej niezrównanym dobrodziejem książnicy kapitulnej był tamtejszy archidiakon Stefan Żuchowski (1666-1716). Bez wątpienia bibliofilstwo było jego pasją. Książki przywoził ze swoich podróży do Rzymu, Wenecji czy innych miast włoskich. Prowadził ożywione kontakty z oficynami drukarskimi, księgarniami czy antykwariatami. Książki kupował ponadto od osób prywatnych. W 1706 roku kapituła sandomierska oceniła Żuchowskiego jako „męża bardzo zasłużonego” zaś na epitafium sporządzonym po jego śmierci i umieszczonym w kolegiacie sandomierskiej zaznaczono, że jego zasługą było urządzenie biblioteki kapitulnej. Inwentarz zbiorów kolegiackich sporządzony w 1712 obejmuje 2089 woluminów z czego jak wskazują dzisiejsze obliczenia not

\footnotetext{
${ }^{14}$ Tamże, s. 213.

${ }^{15}$ Szymański, Kapituła, s. 221; Kumor, Dzieje, t. 3, s. 333.

${ }^{16}$ Kumor, Dzieje, t. 3, s. 400.

${ }^{17}$ Wójcik, Archiwum, s. 38.

${ }^{18}$ Kumor, Dzieje, t. 3, s. 80.
} 
proweniencyjnych oraz zapisów, 530 pochodziło z biblioteki Żuchowskiego. Tytuły tych dzieł wskazują szerokie zainteresowania literaturą naukowa oraz piękną. Wydaje się, że jego celem było nie tylko urządzenie biblioteki kapitulnej (w tym celu zakupił z własnych dochodów drewniane regały), ale również przyświecała mu chęć udostępniania jej zbiorów kapłanom kolegium sandomierskiego. Temu celowi miał służyć chociażby drugi egzemplarz sporządzonego inwentarza książek, przez który zawartość librarii miała być udostępniona kaznodziejom, duchowieństwu oraz wszystkim poszukującym wiedzy. Swoistym ukoronowaniem wysiłków archidiakona sandomierskiego było urzędowe poświadczenie spisu książek przez biskupa krakowskiego Kazimierza Łubieńskiego w dniu 12 kwietnia 1717 roku i nadanie mu w tym dniu Leges conservandae bibliothecae. Dzieło się to jednak już rok po śmierci Żuchowskiego ${ }^{19}$. Warto w tym miejscu zaznaczyć, że tenże biskup w 1708 roku przekazał do biblioteki kapitulnej w Sandomierzu 30 książek, pochodzących z biblioteki po Mikołaju Tarnowskim, kanoniku krakowskim z obowiązkiem, aby korzystający z tych książek mówili de profundis ${ }^{20}$.

O wielkości wkładu archidiakona sandomierskiego z początku XVIII wieku w rozwój biblioteki kapitulnej może również świadczyć fakt, iż na podstawie zapisów proweniencyjnych w zachowanych książkach, kolejnym dobrodziejem tej librarii był ks. Walenty Kazimierz Piotrowicz $(+1719)$, proboszcz w Sobótce, Trześni i Wielowsi, który ofiarował (tylko lub aż 75 dzieł) ${ }^{21}$.

Niezwykle ciekawą drogę, nim trafiły do książnicy sandomierskiej, przebyły książki ks. Kaspra Cichockiego (1545-1616). Ich właściciel posiadał bardzo gruntowne wykształcenie. W 1570 roku uzyskał na Uniwersytecie Krakowskim stopień bakałarza nauk wyzwolonych, ok. 1584 studiował filozofię w Akademii Wileńskiej, następnie w Kolegium Jezuickim w Rzymie. Po powrocie do kraju w 1587 roku przyjął święcenia kapłańskie i osiadł w Sandomierzu. Już rok później ofiarował nieokreśloną ilość książek kapitule sandomierskiej. Z jej polecania w 1595 roku miał z ks. Michałem Kłosińskim dokonać inwentaryzacji biblioteki kolegiackiej. Czy to zadanie zostało zrealizowane, trudno powiedzieć. Trzeba jednak w tym miejscu podkreślić doniosłe wydarzenie z życia Cichockiego, jakim było przyczynienie się do sprowadzenia w 1603 roku jezuitów do Sandomierza oraz ofiarowanie im bogatego księgozbioru. Jak wyżej wspomniano, również i ten zbiór zasilił w końcu XVIII wieku bibliotekę kolegiacką ${ }^{22}$.

Nie sposób wreszcie w tym miejscu pominąć osobę ks. Franciszka Szwarcemberg-Czernego, który w 1775 roku przekazał wikariuszom sandomierskim ponad 500 książek $^{23}$. Owa niezwykła libraria została przewieziona z Krakowa do Sandomierza dopiero pięć lat później ${ }^{24}$.

${ }^{19}$ W. Wójcik, Ksiqdz Stefan Żuchowski (1666-1716), ABMK, 40 (1980) s. 167-169.

${ }^{20} \mathrm{~J}$. Wiśniewski, Katalog prałatów i kanoników sandomierskich od 1186 r. do 1926 r. tudzież sesje kapituly sandomierskiej od 1581 do 1866 r., Radom 1928, s. 193.

${ }^{21}$ Tamże, s. 167.

${ }^{22}$ H. Tadusiewicz, Cichocki Kasper, w: Stownik Pracowników Książki Polskiej, Suplement, red. I. Treichel, Warszawa 1986, s. 37-38.

${ }^{23}$ Wójcik, Archiwum, s. 31.

${ }^{24}$ Wiśniewski, Katalog, s. 45. 
Biblioteki pozostałych kolegiat w diecezji krakowskiej były również zaopatrywane darami książkowymi przez znaczniejszych bibliofilów. Kapituła kielecka otrzymała przed 1642 rokiem 174 księgi. Ofiarodawcą był biskup krakowski Jakub Zadzik (1582-1642). Wśród ofiarowanych dzieł odnajdujemy Roczniki kościelne Cezarego Baroniusza, Statuty Królestwa Polskiego, inwentarz Konstytucji sejmowych, Dekretały Grzegorza IX, Martyrologium Romanum ${ }^{25}$. Właściciel księgozbioru opatrywał swoje dzieła superexlibrisem z herbem Korab i napisem w otoku „Jacobus Zadzik Per Tot Discrimina”26.

W ciekawy sposób w bibliotece kapituły nowosądeckiej znalazły się książki ze zbioru proboszcza w Mystkowie. M. Waculowicz 4 lipca 1618 zezwolił na wybranie poszczególnych dzieł ze swojej biblioteki i przekazanie ich kapitule ${ }^{27}$. Kontynuatorami powiększania librarii kapituły w Nowym Sączu byli jej kanonicy, wśród których można wskazać: w 1637 roku kustosza Bartłomieja Fusoriusza czy w 1717 prepozyta Jana Formankowicza ${ }^{28}$. Warto w tym miejscu zwrócić uwagę na ten ostatni dar. Jego wartość szacowano na sumę 75 florenów polskich. Nie trafił on jednakże do biblioteki kapitulnej, gdyż został rozdany w celu pokrycia długów zmarłego. Można w tym miejscu raz jeszcze zacytować S. Salaterskiego: „Niemniej jednak pewne książki w bibliotece były, skoro wykonawców testamentu kanonika Andrzeja Ziobrowskiego ponaglano, aby oddali książki pożyczone z biblioteki przez zmarłego kanonika, za pozwoleniem dziekana Jana Konstantego Morzkowskiego"29.

Nie wszystkie biblioteki kolegiackie w diecezji krakowskiej doby przedrozbiorowej miały tak hojnych, żywych, dobroczyńców jak sandomierska czy nowosądecka. Często potwierdzenie w źródłach odnośnie powiększania księgozbioru znajdujemy w zapisach testamentowych. Ilustrując tego rodzaju praktykę można wskazać wielkiego darczyńcę dla biblioteki kapituły klimontowskiej - ks. Pawła Rzeczyckiego (1578-1643). Jako pierwszy prepozyt tamtejszej kolegiaty zgromadził pokaźny księgozbiór teologiczny, który testamentem z 21 grudnia 1642 roku miał być przekazany kościołowi parafialnemu w Klimontowie. Jak czytamy w jego biogramie: „Po śmierci testatora powstał spór o prawo własności między kapitułą a klasztorem dominikanów, w którym tymczasowo przechowywana była biblioteka; rozstrzygnął go biskup Piotr Gembicki, nakazując dominikanom zwrócić księgozbiór kościołowi. Umieszczono go zapewne w zakrystii przy prezbiterium budowanego kościoła (...). W 1656 lub 1657 księgozbiór spłonął wraz z częścią kościoła" ${ }^{30}$.

Zapisy testamentowe wzbogacały również bibliotekę kolegiaty sandomierskiej. W 1722 roku wykonawcy ostatniej woli kanonika Sebastiana Dębickiego

\footnotetext{
${ }^{25}$ Kumor, Dzieje, s. 169.

${ }^{26}$ Cz. Erber, Jakub Zadzik, w: Stownik Pracowników, s. 239.

${ }^{27}$ Salaterski, Kolegiata, s. 212.

${ }^{28}$ Kumor, Dzieje, s. 309.

${ }^{29}$ Salaterski, Kolegiata, s. 212.

${ }^{30}$ Rzeczycki Pawel, w: Stownik Pracowników, s. 190.
} 
przekazali do jej zasobu 158 książek po zmarłym, nabytych wcześniej przez niego od kanonika Łukasza Skalskiego ${ }^{31}$.

Podobnie w bibliotece kapituły opatowskiej spotykamy książki pochodzące z pośmiertnych zapisów. Swoją bibliotekę przekazał jej zmarły w 1567 roku Mikołaj Zaleski, prałat dziekan opatowski ${ }^{32}$.

Dary lub zapisy testamentowe stanowiły niekiedy zręby biblioteki kapitulnej, którą z czasem uzupełniano poszczególnymi dziełami. Z taką sytuacją mamy do czynienia w Wojniczu, gdzie fundament księgozbioru kolegiackiego stanowiły dzieła po słynnym szkotyście Michale z Bastrzykowa, altaryście Michale z Wojnicza oraz prepozycie Janie Kwaśnickim, niegdyś uczniem szkół jezuickich ${ }^{33}$.

Trzecim ze wspomnianych sposobów powiększania księgozbioru kolegiackiego były zakupy. W kapitule sandomierskiej tymi sprawami zajmował się prokurator. Jednakże sumy przeznaczane na ten cel nie były wysokie, gdyż od 1659 roku środki na zakup zaczęto czerpać z dochodów anni gratiae - sum składanych przez nowo mianowanych kanoników. W XVIII wieku koszty zakupu książek zaczęto pokrywać ex massa portionum - funduszów przeznaczonych dla kanoników. Oczywiście, nie były to środki, które mogłyby pozwolić na zgromadzenie doborowego księgozbioru zadowalającego wszystkich członków kapituły. Stąd znane są przypadki składania prywatnych ofiar na książki, lub też kupowania ich przez pojedyncze osoby, np. kantora ${ }^{34}$. Motywem zakupów były nie tylko chęć zdobycia wiedzy, powiększenie księgozbioru czy uświetnienia Służby Bożej, ale także napomnienia biskupie, aby uzupełniano brakujące księgi liturgiczne ${ }^{35}$. Tytułem egzemplifikacji można wskazać występujący w aktach kapituły sandomierskiej zapis umieszczony pod 1722 rokiem, aby po zmarłym kanoniku Łukaszu Skalskim nabyć 16 książek za 158 florenów i przekazać je do biblioteki kapitulnej $^{36}$.

Pieniądze za które kupowano nowe książki do biblioteki pochodziły ponadto ze sprzedaży dubletów dzieł, przechowywanych w librariach. Pochodzące z darowizn oraz zapisów dzieła wydzielano, z czego nierzadko korzystali kanonicy, kupując je do własnych bibliotek. Taką praktykę spotykamy w kręgu kolegiaty sandomierskiej gdzie na posiedzeniu kapituły w 1725 roku polecono kanonikom Jakubowi Orzechowskiemu oraz Janowi Franciszkowi Kaliszowi duplikaty książek zamienić na inne lub sprzedać a z uzyskanych dochodów dokonać zakupów nowych dzieł w Gdańsku ${ }^{37}$. Jako ilustrację tej praktyki można także wskazać uchwałę kapituły sandomierskiej z 9 września 1727 roku, aby nieużywane książki francuskie sprzedać, a za uzyskane pieniądze zakupić dzieła kaznodziejskie. Ostatecz-

${ }^{31}$ Wiśniewski, Katalog, s. 49.

${ }^{32}$ A. Bastrzykowski, Kolegiata św. Marcina w Opatowie i jej kapituła, cz. 2, Katalog pratatów i kanoników kolegiaty opatowskiej od 1212 roku aż do dni naszych, Ostrowiec Świętokrzyski 1948, s. 87.

${ }^{33}$ Szymański, Kapituła, s. 222.

${ }^{34}$ Wójcik, Archiwum, s. 32-33.

${ }^{35}$ Tamże, s. 32.

${ }^{36}$ Wiśniewski, Katalog, s. 137.

${ }^{37}$ Tamże, s. 141. 
nie otrzymali je kanonicy Jacek Łopacki i Michał Wodzicki zobowiązując się w zamian do dostarczenia książek kaznodziejskich. Wymiana nie została sfinalizowana w ciagu roku, gdyż na posiedzeniu kapituły 9 września 1729 roku podjęto uchwałę, aby upomnieć się o książki obiecane przez tych kanoników. Definitywnie przyrzeczone bibliotece dzieła kanonicy przesłali w $1730^{38}$.

Podobne praktyki widoczne są w źródłach dotyczących działalności innych korporacji kanonickich. Kapituła wojnicka podjęła w 1681 roku uchwałę o uzupełnieniu biblioteki, z pewnością drogą zakupu, dziełami z zakresu teologii moralnej i kaznodziejstwa ${ }^{39}$.

Jeśli duplikaty nie znajdowały nabywcy, były niekiedy przekazane do parafii na użytek pracujących tam duszpasterzy. Taką praktykę spotykamy w Sandomierzu, gdzie 9 września 1732 roku podjęto uchwałę, aby do Samborca przekazać kapę koloru czerwonego i niektóre duplikaty książek ${ }^{40}$.

\section{Przechowywanie książek}

Protokoły powizytacyjne kolegiat posiadają wiele zaleceń, które wizytatorzy kierowali do kapituł w kwestii przechowywania księgozbioru. Odpowiedzialność za ich stan spoczywała na biskupach, zaś sprawy związane z ich funkcjonowaniem rozwiązywano na posiedzeniach kapituły. W kolegiacie sandomierskiej libraria była połączona $\mathrm{z}$ archiwum i przechowywana $\mathrm{w}$ jednym lokalu, stąd opiekę nad nimi sprawował kustosz lub w jego imieniu wicekustosz. Czuwał on ponadto nad wypożyczaniem książek oraz pracami w bibliotece wykonywanymi z jego polecenia przezwyznaczonychkanoników ${ }^{41}$.PodobnąsytuacjęodnajdujemywOpatowie, gdzie kustosz lub podkustosz przechowywali klucze od skarbca kapitulnego w którym znajdowały się archiwum i biblioteka ${ }^{42}$. Statuty tej wspólnoty kanonickiej z 1728 roku zlecały troską o księgozbiór notariuszowi ${ }^{43}$. Również w Tarnowie kustosz miał pod swoja opieką skarbiec, zakrystię, archiwum, bibliotekę, naczynia i szaty liturgiczne ${ }^{44}$. Z kolei w Nowym Sączu archidiakon Jan Januszowski nakazał w 1608 roku zmianę miejsca biblioteki przechowywanej dotychczas w skarbcu nad zakrystią, którą umieszczono między więżą północną nad portykiem a chórem bractwa literackiego ${ }^{45}$. Wojnicką librarię umieszczono w szafie w skarbcu kolegiackim ${ }^{46}$.

\footnotetext{
${ }^{38}$ Wójcik, Archiwum, s. 33; Wiśniewski, Katalog, s. 142-144.

${ }^{39}$ Kumor, Dzieje, t. 3, s. 333.

${ }^{40}$ Wiśniewski, Katalog, s. 145.

${ }^{41}$ Wiśniewski, Katalog, s. 18; Kumor, Dzieje, t. 3, s. 35; 80.

${ }^{42}$ Gałązka, Kapituła, s. 242-243.

${ }^{43}$ Tamże, s. 183.

${ }^{44}$ Kumor, Dzieje, t. 3, s. 227.

${ }^{45}$ Tamże, s. 309.

${ }^{46}$ Szymański, Kapituła, s. 221.
} 
Troska o księgozbiór kolegiaty sandomierskiej wyrażała się ponadto wprowadzeniem specjalnego tytułu - bibliothecarius. Pierwszym kanonikiem, który piastował ta funkcję był prepozyt klimontowski Wawrzyniec Boxa Radoszewski ${ }^{47}$.

Wizytujący kolegiatę sandomierska w 1595 roku kardynał Jerzy Radziwiłł nakazał umieścić bibliotekę w skarbcu lub w szafie w zakrystii mansjonarzy ${ }^{48}$. Mogło to sugerować, że dotychczas libraria nie była w należyty sposób przechowywana. Z polecenia kapituły, pracę tą mieli wykonać kanonicy Kasper Cichocki i Maciej Kłosiński w terminie do uroczystości Trzech Króli 1596 roku. Ponadto zlecono im sporządzenie inwentarza ${ }^{49}$. Niestety, polecenie nie zostało wykonane, gdyż ponowiono je na wrześniowej sesji kapituły w 1596 roku. Ten problem wystapił ponownie w połowie XVII wieku, gdyż w 1651 roku czytamy w uchwałach z posiedzeń kapituły o zaniedbaniach $\mathrm{w}$ kwestii biblioteki, której wiele lat nie kontrolowano i nie wietrzono, książki pokryte kurzem znajdowały się w wielkim nieładzie, pomimo upomnienia skierowanego rok wcześniej przez biskupa lipskiego do prokuratora by dbał o porządek w książkach ${ }^{50}$. Wizytujący kolegiatę rok później biskup Piotr Gembicki rozkazał sporządzenie szafy w której należało ułożyć książki wg bliżej nieznanego ustalonego porządku oraz utrzymywać ich w czystości. Ponadto zobowiązał kapitułę do sporządzenia inwentarza ksiag i oddanie jej pod opiekę jednego z rezydentów ${ }^{51}$. Odpowiedzią kapituły na wymienione zalecenia była uwaga skierowana pod adresem prokuratora, aby chronił książki przed kurzem i wilgocią. Ponadto poinformowano go o możliwości dochodzenia restytucji za straty poniesione przez bibliotekę. Ponadto pod groźbą utraty dystrybucji wicekustosz kolegiaty miał w ciagu miesiąca wydzielić i spisać książki, przydatne kaznodziejom ${ }^{52}$. Prace nad uporządkowaniem biblioteki kontynuowano w XVIII wieku. W 1707 roku na posiedzeniu kapituły w dniu 18 lutego wyznaczono kanoników Łukasz Skalskiego i Jakuba Orzechowskiego, którzy mieli zrewidować zasób książkowy miejscowej kolegiaty. Jednakże prawdziwym dobrodziejem biblioteki kapitulnej stał się wspomniany wyżej archidiakon sandomierski Stefan Żuchowski. W 1710 roku ufundował regały na książki, które zamontowano w sali posiedzeń kapituły ${ }^{53}$. Dzięki temu, pokaźny zasób książkowy znalazł właściwe dla siebie miejsce. Pojawiała się jednak niedogodność w postaci nieustannej troski o księgozbiór, który umieszczony w widocznym miejscu winien być uporządkowany. Ze nie zawsze tak było, świadczą postanowienia kapituły w późniejszym okresie. Już w 1719 roku do uporządkowania książek kapituła sandomierska skierowała kanoników Jana Franciszka Kalisza, Kazimierza Cejplera i Jakuba Orzechowskiego ${ }^{54}$. Po dziewięciu latach troskę o porządek w bibliotece zlecono kanonikowi Franciszkowi Omańskiemu, który miał ponadto za

\footnotetext{
${ }^{47}$ Wójcik, Archiwum, s. 31-32.

${ }^{48}$ Tamże, s. 31.

${ }^{49}$ Wiśniewski, Katalog, s. 16.

${ }^{50}$ Tamże, s. 60.

${ }^{51}$ Tamże, s. 65.

${ }^{52}$ Wójcik, Archiwum, s. 34-35.

${ }^{53}$ Wójcik, Ksiądz, 162-163.

${ }^{54}$ Wiśniewski, Katalog, s. 134.
} 
wynagrodzeniem podwójnej dystrybucji tygodniowej i 50 florenów sporządzić jej inwentarz ${ }^{55}$. Podobną sytuację spotykamy w 1774 roku, kiedy to stwierdzono nieład w księgozbiorze i polecono, by wyznaczyć dwóch kanoników którzy mieli zebrać księgi i ułożyć je według treści. Praca ta została zrealizowana o czym świadczą napisy na zachowanych do dnia dzisiejszego regałach ${ }^{56}$.

Troska kapituły sandomierskiej o księgozbiór wyrażała się ponadto w zabiegach mających na celu zachowanie librarii w całości. Świadczą o tym notatki sporządzane na stronach inkunabułów: „Ecclesiae collegiatae Sandomiriensi pertinens”, „Bibliothecae ecclesiae collegiatae Sandomieriensis”. Ponadto, jak napisał W. Wójcik „Obowiązek troski wzrastał, gdy ofiarodawca lub egzekutor testamentu wypisywał na okładce tytułowej specjalne przeznaczenie książki: „Ecclesiae collegiatae Sandomiriensis in usum concionatorum et scriptorum albo też Legatus in usum concionatorum et pauperum sacerdotum”. Zachęta do pilnego strzeżenia książki był także nakaz skierowany przez spadkobierców testatora do duchownych kościoła kolegiackiego ,,pro anima eius orate”. W wypadku napotkania u osób obcych książki podpisanej „nomine bibliothecae capituli” kanonicy informowali o tym na posiedzeniu gremium kapituły $i$ wtedy zarządzano rewindykację własności wspólnej przez prokuratora lub wydelegowanego kanonika" ${ }^{57}$.

Napomnienia biskupie dotyczące stanu pozostałych bibliotek kolegiackich w diecezji krakowskiej ukazują potrzebę nieustannej troski o ich stan. Tytułem egzemplifikacji można wskazać uwagę sporządzona przez biskupa Felicjana Konstantego Szaniawskiego pod adresem librarii nowosądeckiej w której zauważa, że nie była otaczana należnąjej troską ${ }^{58}$. Statuty kapituły wojnickiej z 25 lutego 1664 roku nakazywały wprost zwrot książek kościelnych znajdujących się poza Wojniczem i ich staranne przechowywanie ${ }^{59}$.

\section{Inwentarze biblioteczne}

Ponadto, jak wyżej wspomniano, kapituły co pewien czas rewidowały stan swoich księgozbiorów sporządzając inwentarze. Można w tym miejscu wskazać kolegiatę w Skalbmierzu, gdzie w protokole powizytacyjnym z 1607 roku znajdujemy wzmiankę o poleceniu kapituły wydanym jednemu z kanoników, by spisał bibliotekę $^{60}$. Nowosądecka libraria została zweryfikowana z inwentarzem w 1760 roku w przeciagu 3 dni przez kanonika Marcina Mikołaja Troynarskiego ${ }^{61}$. Inwentarz biblioteczny obejmujący 66 pozycji zachował się dla librarii wojnickiej.

\footnotetext{
${ }^{55}$ Wiśniewski, Katalog, s. 142; W. Wójcik, Archiwum, s. 35.

${ }^{56}$ Wójcik, Archiwum, s. 34.

${ }^{57}$ Tamże, s. 33.

${ }^{58}$ Salaterski, Kolegiata, s. 211.

${ }^{59}$ Szymański, Kapituła, s. 208.

${ }^{60}$ Kumor, Dzieje, t. 3, s. 194.

${ }^{61}$ Salaterski, Kolegiata, s. 211-212.
} 
Można w nim wyodrębnić trzy grupy, pochodzące od ofiarodawców: Michała z Bastrzykowa, Michała z Wojnicza i Jana Kwaśnickiego ${ }^{62}$.

Niewatpliwie jedna ze znaczniejszych bibliotek znajdowała się przy kolegiacie w Wiślicy. Pierwszy znany katalog tej książnicy został w 1480 roku sporządzony przez kanonika krakowskiego i kustosza wiślickiego Jana Gosławskiego przy współpracy Jana Starzechowskiego oraz Jana Rzeszowskiego. Nosi on tytuł Libri in libraria ecclesiae Vislicensis i obejmuje 37 dzieł. Zestawione osobno księgi liturgiczne liczą 29 tytułów. Podobne spisy sporządzono na przełomie XVI/ XVII wieku ${ }^{63}$. Dla poznania dziejów tej biblioteki niezwykle cennym jest również „Katalog ksiąg wikariuszy kolegiaty wiślickiej” z 1599 roku. Obejmuje on 132 księgi $^{64}$. Podobna liczba woluminów (ok. 130) mogła wykazać się w tym czasie również biblioteka kolegiacka w Tarnowie ${ }^{65}$.

Jednakże spośród bibliotek kolegiackich w diecezji krakowskiej liczebnością woluminów wyróżniała się sandomierska. Katalog sporządzony w 1729 roku przez wicekustosza Jana Franciszka Kuhna został pogrupowanyna 18 działów i obejmuje 2111 woluminów ${ }^{66}$.

Niewiele informacji zachowało się dla biblioteki kolegiackiej w Lublinie. W 1596 roku liczyła 5 mszałów, 3 agendy, 2 graduały, 2 antyfonarze, księgi potrzebne do liturgii chórowej, zaś książki przechowywane w librarii kapitulnej były nieuporządkowane ${ }^{67}$.

\section{Korzystanie z biblioteki}

Wypożyczanie książek z bibliotek kapitulnych regulowały ich statuty. Tytułem egzemplifikacji można wskazać kodyfikację sandomierskiej kolegiaty z 1629 roku, w myśl której książki mogli otrzymywać tylko prałaci i kanonicy. Nie mogli oni jednak wywozić książek poza teren miasta. Zbiór z 1713 zacieśnił grono uprawnionych do wypożyczania do kanoników kaznodziei, rezydujących przy kolegiacie. Dalsze uchwały wskazują jednak, że z librarii korzystali wszyscy członkowie kapituły ${ }^{68}$. Książki wypożyczał wicekustosz. Bez jego zgody, pod groźbą kary wyznaczonej przez biskupa, nie wolno było wynosić żadnej książki. Wypożyczający miał obowiązek złożenia rewersu w którym podawał swoje imię i nazwisko, tytuł wypożyczonej książki oraz datę jej zwrotu ${ }^{69}$. Podobne uwarunkowania funkcjonowały w kapitule opatowskiej. Gdy ktoś chciał po okresie wypożyczenia nadal korzystać z książki, musiał na rewersie wpisać nowy termin jej zwrotu. $\mathrm{Z}$ wpisywania na rewersie terminu zwrotu zwolnieni byli kanonicy ka-

\footnotetext{
${ }^{62}$ Szymański, Kapituła, s. 221-222.

${ }^{63}$ Szczegółowo zostały one przedstawione przez P. Kardysia, Biblioteka, s. 85-95.

${ }^{64}$ Kumor, Dzieje, t. 3, s. 128.

${ }^{65}$ Tamże, s. 263-265.

${ }^{66}$ Tamże, s. 81.

${ }^{67}$ Tamże, s. 381.

${ }^{68}$ Wójcik, Archiwum, s. 36.

${ }^{69}$ Tamże, s. 36.
} 
znodzieje i penitencjarze ${ }^{70}$. Mimo powyższych przepisów regulujących wypożyczanie książek, w aktach kapitulnych spotykamy informacje o ich przetrzymywaniu. We wspomnianym Opatowie jeden z kanoników - Stanisław Zagórski posiadał książki z biblioteki kapitulnej, które zostały odebrane od niego przez prałata scholastyka Makarego Rzeczyckiego ${ }^{71}$. W przypadku kolegiaty nowosadeckiej mamy do czynienia raczej z wyniesieniem biblioteki. Jej kustosz - Stanisław Gralski - w 1592 roku wypożyczył bowiem, wg przekazu archidiakona Januszowskiego z 1608 roku, 505 książek $^{72}$.

\section{Zakończenie}

Ukazane procesy gromadzenia, przechowywania, opracowywania i udostępniania zbiorów wskazują na ważną role, jaką odgrywały te librarie nie tylko w życiu kapituły, ale też miejsc w których one funkcjonowały. Są świadectwem zainteresowań kulturalnych kanoników, wyrazem ich troski o rozwój intelektualny członków kapituł oraz świadczą o dużym wkładzie w dbałość o Służbę Bożą w kolegiatach. Zbadanie zawartości treściowej bibliotek w oparciu o zachowane dzieła $\mathrm{i}$ inwentarze, odczytanie not proweniencyjnych oraz notatek marginalnych, analiza miejsc druku i opraw, to tylko niektóre kierunki badań, które należałoby podjąć w celu kompleksowego opracowania dziejów bibliotek kolegiackich w diecezji krakowskiej okresu staropolskiego.

\footnotetext{
${ }^{70}$ W. Gałązka, Kapituła, s. 213.

${ }^{71}$ A. Bastrzykowski, Kolegiata, s. 87.

${ }^{72}$ B. Kumor, Dzieje, t. 3, s. 309.
} 